\title{
Tinggalan Arkeologi di Pura Penataran Kacang Bubuan Mas
}

\author{
Mochamad Irfan*, I Wayan Srijaya, Coleta Palupi Titasari \\ Prodi Arkeologi, Fakultas Ilmu Budaya, Unud \\ [irfantubix@gmail.com],[arkeologi_unud@yahoo.co.id], [anjunary@yahoo.com] \\ Denpasar, Bali, Indonesia \\ *Corresponding Author
}

\begin{abstract}
In Bali, the archaeological remains is still functioned and sanctified by the public by placing them in a temple, one of them is Penataran Kacang Bubuan Mas Temple, Ubud, Gianyar regency. The methodin this study is a qualitative committee method which will produce desktiptif data in the form of written words. Data analyis being applied in this research is the qualitative analysis,iconography analysis and contextual analysis. Some theories being applied in this research is the functional theory and semiotics theory. Based on the analysis, the conclusions are drawn in the form of archaeological heritage of 1 piece Ganesha statue, 1 piece simpel statue (primitive statue), 6 pieces embodiment statues of bhatari, 2 pieces embodiment statues of bhatara, 1 piece lingga (tribhaga), 2 pieces animal statues, 1 piece priest statue, 1 pieces clownman statue, 4 pieces fragments of statues, 1 piece fragment waterless building fragment, 1 piece natural stone. Archaelogical remains in Penataran Kacang Bubuan Mas Temple, Ubud, Gianyar regency when viewed from its function in the past has experienced a shift function. The local community is still sanctify archaeological remains as a workship tool to ask for safety and protection from harm and fertility. The meaning of the archaeological remains found in the temple is sacred objects for the means of worship by the penyungsung pura community. The means of worshiping the requested statues is symbolism or symbolic that connects worshipers with gods, ancestral holy spirits or for Sang Hyang Widhi Wasa (God).
\end{abstract}

Keywords: archaeological remains, statue, iconography

\begin{abstract}
Abstrak
Di Bali, tinggalan arkeologi sampai saat ini masih difungsikan dan disakralkan oleh masyarakat dengan cara disimpan dalam pura, salah satunya di Pura Penataran Kacang Bubuan Mas, Ubud, Kabupaten Gianyar. Metode dalam penelitian ini ialah metodologi kualitatif dengan menghasilkan data deskriptif berupa kata-kata tertulis. Analisis data yang digunakan dalam penelitian ini adalah analisis kualitatif, analisis ikonografi dan analisis kontekstual. Beberapa teori yang digunakan dalam penelitian ini adalah teori fungsional dan teori semiotika. Berdasarkan hasil analisis dapat ditarik simpulan bahwa dengan bentuk tinggalan arkeologi berupa 1 buah arca ganesa, 1 buah arca sederhana (arca primitif), 6 buah arca perwujudan bhatari, 2 buah arca perwujudan bhatara, 1 buah lingga (tribhaga), 2 buah arca binatang, 1 buah arca pendeta, 1 buah arca punakawan, 4 buah fragmen arca, 1 buah fragmen kemuncak bangunan, 1
\end{abstract}


buah batu alam. Tinggalan arkeologi di Pura Penataran Kacang Bubuan Mas, Ubud, Kabupaten Gianyar sampai saat ini masih dikeramatkan oleh masyarakat setempat dan difungsikan sebagai media pemujaan untuk memohon keselamatan, perlindungan dari marabahaya dan kesuburan. Makna dari tinggalan arkeologi yang terdapat di Pura tersebut adalah sebagai benda-benda yang disakralkan untuk sarana pemujaan oleh masyarakat penyungsung pura. Sarana pemujaan terhadap arca-arca yang dimaksud adalah suatu perlambangan atau simbolis yang menghubungkan pemujanya dengan dewa-dewi, roh suci leluhur atau kepada Sang Hyang Widhi Wasa (Tuhan).

\section{Kata kunci: tinggalan arkeologi, arca, ikonografi}

\section{Latar Belakang}

Sejarah bangsa Indonesia secara kronologis meliputi masa Prasejarah, masa Klasik (Hindu-Budha), masa pengaruh Islam dan masa pengaruh Eropa. Bangsa Indonesia sejak dahulu memiliki kebudayaan yang sangat tinggi, setelah masuknya pengaruh Hindu barulah bangsa Indonesia mengenal tulisan yang dianggap sebagai jenjang memasuki jaman sejarah dan jaman klasik. Banyak unsur Hindu yang berpengaruh di Indonesia seperti unsur agama (Hindu dan Budha) dan kebudayaan yang meliputi seni sastra, seni pahat, arsitektur, sistem pemerintahan, dan lain-lain (Titasari, 2008: 213).

Pulau Bali atau biasa disebut pulau Dewata merupakan sebuah pulau yang memiliki keindahan dan keunikan baik dari segi bentang alam, tingkah laku kehidupan masyarakat Bali yang spesifik, adat-istiadatnya, seni budaya serta tinggalan arkeologinya (Ardana, 1977: 1). Bali juga dianggap sebagai pulau dengan seribu puranya. Maka tak dapat dipungkiri lagi nilai kereligiusan yang ada juga sangatlah kental. Pada umumnya masyarakat Bali mempunyai kesadaran yang tinggi tentang masa lampau karena tidak lepas dari kehidupan sosial religius masyarakat dalam desa adat.
Media pemujaan di Bali sebelum mengenal pemujaan kepada patung dewa, awalnya dilakukan kepada roh nenek moyang yang dianggap berjasa dan dapat melindungi keturunan dan masyarakatnya yang diwujudkan dalam bentuk menhir, punden berundak, dan arca yang memiliki bentuk yang sederhana. Konsepsi pemujaan terhadap roh nenek moyang sudah berkembang dan dikenal pada masa prasejarah hingga sekarang. Pada masa prasejarah pemujaan tertinggi dilakukan terhadap roh pemimpin atau kepala suku yang dianggap berjasa dalam melindungi masyarakat pada masa itu (Soekmono, 1973: 76).

Pemujaan terhadap dewa-dewa dan penghormatan terhadap roh nenek moyang pada masa klasik biasanya digambarkan dalam sebuah wujud atau simbol-simbol dalam bentuk arca dewa, arca perwujudan dan lingga. Seni arca yang dibuat dalam bentuk arca dewa dipergunakan untuk mengadakan hubungan dengan dewa-dewa yang digambarkan atau dengan perkataan lain arca-arca tersebut merupakan mediator (Maulana, 1984: 5).

Kabupaten Gianyar diketahui banyak menyimpan arca-arca yang memiliki nilai sejarah yang tinggi dan salah satunya disimpan di Pura Penataran Kacang Bubuan Mas, Ubud, Kabupaten Gianyar. Hal ini dapat dilihat dari tinggalan arca- 
arca yang berasal dari zaman megalitik, dan arca yang berasal dari zaman klasik, yang merupakan peninggalan sejarah yang tetap terjaga di dalam pura.

Terkait dengan data arkeologi yang terdapat di Pura Penataran Kacang Bubuan Mas, Ubud, Kabupaten Gianyar penulis tertarik untuk melakukan penelitian lebih lanjut karena ada beberapa hal yang masih perlu dibahas secara rinci, khususnya pada pembahasan arcanya seperti bentuk (ikonografi), fungsi masa lalu maupun fungsi masa sekarang serta makna pada tinggalan arkeologi di Pura Penataran Kacang Bubuan Mas, Ubud, Kabupaten Gianyar.

Selain itu dikarenakan arca memiliki sifat yang rentan mengalami kerusakan sehingga dapat menghilangkan bentuk, fungsi dan makna serta beberapa aspekaspek lainnya yang terkandung di dalam tinggalan arkeologi tersebut, maka diperlukannya penelitian yang lebih intensif.

\section{Pokok Permasalahan}

a) Tinggalan arkeologi apa saja yang terdapat di Pura Penataran Kacang Bubuan Mas, Ubud, Kabupaten Gianyar?

b) Apakah fungsi dan makna tinggalan arkeologi yang terdapat di Pura Penataran Kacang Bubuan Mas, Ubud, Kabupaten Gianyar?

\section{Tujuan Penelitian}

a) Untuk mengetahui bentuk tinggalan arkeologi yang terdapat di Pura Penataran Kacang Bubuan Mas, Ubud, Kabupaten Gianyar.

b) Untuk mengetahui fungsi dan makna tinggalan arkeologi yang terdapat di Pura Penataran Kacang Bubuan Mas, Ubud, Kabupaten Gianyar.

\section{Metode Penelitian}

Adapun metode yang digunakan dalam penelitian ini terdiri dari beberapa tahapan. Tahap Pertama yaitu teknik pengumpulan data dilakukan dengan cara observasi, wawancara, dan studi kepustakaan. Data-data tersebut dapat bersumber dari naskah, wawancara, catatan lapangan, maupun sebuah dokumen yang kemudian dideskripsikan, dirangkai, serta disusun secara sistematis sehingga dapat memberikan kejelasan terhadap kenyataan atau realitas dari suatu permasalahan yang akan diteliti. Tahap kedua yaitu menganalisis data menggunakan anallisis kualitatif, ikonografi, dan kontekstual. Data yang telah terkumpul selanjutnya dikembangkan dengan menggunakan teori fungsional dan teori semiotika. Penggunaan teori ini dalam pengembangan data juga memudahkan penulis dalam mengkaji dan memecahkan permasalahan penelitian.

\section{Hasil dan Pembahasan}

5.1 Bentuk Tinggalan Arkeologi di Pura Penataran Kacang Bubuan Mas, Ubud, Kabupaten Gianyar

Bentuk tinggalan arkeologi di Pura Penataran Kacang Bubuan Mas, Ubud, Kabupaten Gianyar memiliki bentuk dan ukuran yang bervariasi serta beragam. Adapun tinggalan arkeologi arca di pura tersebut yaitu berupa 6 buah arca perwujudan bhatari, 2 buah arca perwujudan bhatara, 1 buah arca ganesha, 1 buah arca sederhana (primitif), 1 buah lingga (tribhaga), 1 buah arca pendeta, 1 buah arca punakawan, 2 buah arca binatang, 4 buah fragmen arca, 1 buah fragmen kemuncak bangunan, 1 buah batu alam. Tinggalan arkeologi di Pura Penataran Kacang Bubuan Mas, Ubud, Kabupaten Gianyar terbuat atau berbahan dari batu padas berwana abu-abu. Kemungkinan arca-arca perwujudan yang terdapat di pura tersebut tidak semua merupakan arca perwujudan raja, akan tetapi juga merupakan perwujudan dari 
tokoh terkemuka dalam masyarakat pada waktu itu.

\subsection{Fungsi Tinggalan Arkeologi di Pura Penataran Kacang Bubuan Mas, Ubud, Kabupaten Gianyar \\ Fungsi tinggalan arkeologi di Pura} Penataran Kacang Bubuan Mas, Ubud, Kabupaten Gianyar yaitu jika ditinjau dari masing-masing tinggalan arkeologi berupa arca perwujudan bhatari dan bhatara, arca ganesha, arca sederhana (primitif), lingga (tribhaga), arca pendeta, arca punakawan, arca binatang, fragmen arca, fragmen kemuncak bangunan, batu alam, pada masa lampau kiranya pasti memiliki suatu fungsi yang berbeda-beda antara tinggalan arkeologi yang satu dengan yang lainnya. Arca perwujudan bhatari dan bhatara memiliki fungsi sebagai perwujudan dari tokoh seorang raja atau tokoh masyarakat yang disegani yang pernah berkuasa dan meninggal untuk memohon perlindungan, kemakmuran dan memohon kesejahteraan bagi masyarakat. Arca Ganesha memiliki fungsi sebagai dewa pelindung, dewa penolak marabahaya dan rintangan, dewa penyelamat dan kebijaksanaan. Arca sederhana (primitif) memiliki fungsi sebagai media pemujaan penghormatan terhadap roh suci leluhur yang telah meninggal. Lingga memiliki fungsi sebagai lambang pemujaan terhadap Dewa Siwa yang merupakan simbol atau lambang dari kesuburan. Arca pendeta memiliki fungsi sebagai tokoh penyebar agama Hindu pertama ke Asia Tenggara hingga Indonesia. Arca punakawan memiliki fungsi sebagai teman, pendamping atau pengasuh (pamong), mengingat tugas punakawan adalah sebagai penasehat atau pengasuh dari tokoh sentral yang dalam hal ini bisa berwujud raja, satria ataupun dewa, sehingga kedudukan punakawan harus selalu berada dekat dengan tokoh tersebut. Arca binatang memiliki fungsi sebagai dekoratif (hiasan) dari sebuah bangunan suci. Unsur bangunan memiliki fungsi sebagai pelengkap arsitektur dari sebuah bangunan suci.

Tetapi pada masa kini tinggalan arkeologi tersebut mengalami suatu kesinambungan fungsi, yaitu sebagai pemujaan kepada Sang Hyang Widhi Wasa (Tuhan) dengan segala manifestasnya. Tinggalan arkeologi tersebut oleh masyarakat dijadikan sebagai media untuk memohon keselamatan, perlindungan dari marabahaya, serta memohon kesuburan.

Tinggalan arkeologi yang terdapat di pura tersebut oleh masyarakat sampai sekarang ini masih dipuja, disucikan dan dikeramatkan oleh penyungsungnya yang dianggap memiliki kekuatan magis. Pada saat Piodalan di Pura Penataran Kacang Bubuan Mas, Ubud, Kabupaten Gianyar, maka arca-arca tersebut dihaturkan sesajen. Pada saat Piodalan inilah semua masyarakat atau penyungsung pura mengadakan upacara persembahyangan bersama, dan juga melakukan pemujaan kepada arca-arca tersebut. Pemujaan dilakukan dengan tujuan untuk memohon perlindungan, keselamatan, kesejahteraan dan kesuburan bagi masyarakat setempat (wawancara dengan Jro Mangku I Nyoman Subrata dan I Nyoman Suweca, ).

\subsection{Makna Tinggalan Arkeologi di Pura Penataran Kacang Bubuan Mas, Ubud, Kabupaten Gianyar \\ Makna simbolis dari tinggalan-} tinggalan arkeologi yang terdapat di Pura Pura Penataran Kacang Bubuan Mas, Ubud, Kabupaten Gianyar yaitu sebagai tinggalan-tinggalan arkeologi yang disakralkan dan memiliki nilai emas bagi masyarakat penyungsung pura. Makna denotatif pada kata "emas" yang dimaksud yaitu perhiasan (logam mulia) atau warna. Makna konotatif pada kata 
"emas" yaitu sesuatu yang tinggi mutunya (berharga, bernilai).

Kesimpulan dari uraian diatas yaitu tinggalan-tinggalan arkeologi yang ada di Pura Penataran Kacang Bubuan Mas, Ubud, Kabupaten Gianyar dipercayai oleh masyarakat bahwa segala sesuatu yang berkaitan dengan roh suci leluhur ataupun kepada Sang Hyang Widhi Wasa (Tuhan) dianggap penting, berharga dan bernilai tinggi sehingga harus tetap dijaga dan dihormati yang dijadikan sebagai sarana pemujaan oleh masyarakat penyungsung pura. Sarana pemujaan terhadap arca-arca yang dimaksud adalah suatu media yang menghubungkan pemujanya dengan dewa-dewi, roh suci leluhurnya maupun kepada Sang Hyang Widhi Wasa atau Tuhan Yang Maha Esa.

\section{Simpulan}

Berdasarkan uraian dari pembahasan di atas, maka akan diuraikan mengenai kesimpulan permasalahan yang dikaji dalam penelitian ini yaitu : Bentuk tinggalan arkeologi di Pura Penataran Kacang Bubuan Mas, Ubud, Kabupaten Gianyar memiliki bentuk dan ukuran yang bervariasi serta beragam. Adapun tinggalan arkeologi arca di pura tersebut yaitu berupa 6 buah arca perwujudan bhatari, 2 buah arca perwujudan bhatara, 1 buah arca ganesha, 1 buah arca sederhana (arca primitif), 1 buah lingga (tribhaga), 1 buah arca pendeta, 1 buah arca punakawan, 2 buah arca binatang, 4 buah fragmen arca, 1 buah fragmen kemuncak bangunan, 1 buah batu alam.

Fungsi tinggalan arkeologi di Pura Penataran Kacang Bubuan Mas, Ubud, Kabupaten Gianyar di tengah-tengah masyarakat yaitu jika ditinjau dari masing-masing tinggalan arkeologi berupa arca perwujudan bhatari dan bhatara, arca ganesha, arca sederhana (arca primitif), lingga (tribhaga), arca pendeta, arca punakawan, arca binatang, fragmen arca, unsur bangunan, batu alam, sudah tentu pemujaan kepada Sang Hyang Widhi Wasa (Tuhan) dengan segala manifestasnya. Tingggalantinggalan tersebut oleh masyarakat mempercayai sebagai sarana pemujaan untuk memohon keselamatan dan perlindungan dari marabahaya, serta memohon kesuburan. Tinggalan arkeologi yang terdapat di pura tersebut oleh masyarakat sampai sekarang ini masih dipuja, disucikan dan dikeramatkan oleh penyungsungnya yang dianggap memiliki kekuatan magis.

Makna simbolis tinggalan arkeologi di Pura Penataran Kacang Bubuan Mas, Ubud, Kabupaten Gianyar yaitu sebagai tinggalan arkeologi yang disakralkan dan dipercayai oleh masyarakat bahwa segala sesuatu yang berkaitan dengan dewadewi, roh suci leluhur atau kepada Sang Hyang Widhi Wasa (Tuhan) dianggap penting, berharga dan bernilai tinggi sehingga harus tetap dijaga dan dihormati yang dijadikan sebagai sarana pemujaan oleh masyarakat penyungsung pura. Sarana pemujaan terhadap arca-arca yang dimaksud adalah suatu perlambangan atau simbolis yang menghubungkan pemujanya dengan dewa-dewi, roh suci leluhur atau kepada Sang Hyang Widhi Wasa (Tuhan).

\section{Daftar Pustaka}

Ambarawati, Ayu. 2011. "Tinggalan Arkeologi Di Pura Gunung Sekar, Desa Sangsit, Kecamatan Sawan, Kabupaten Buleleng". Forum Arkeologi. No. 3, November 2011 (224 - 234). Balai Arkeologi Denpasar.

Ardana, I Gusti Gde. 1971. Pengertian Pura di Bali. Proyek Pemeliharaan dan Pengembangan Kebudayaan Daerah Bali. t.p 
Bagus, A.A. Gde. 2015. "Arca Ganesa Bertangan Delapan Belas Di Pura Pingit Melamba Bunutin, Kintamani, Bangli”. Forum Arkeologi. Volume 28, Nomor 1, April 2015 (25-34). Balai Arkeologi Denpasar.

Basudewa, Dewa Gede Y. 2015. "Fungsi Lingga Yoni di Pura Dangka Tembawu Denpasar". Pustaka Jurnal Ilmu-ilmu Budaya, Volume XV, No 1 Februari 2015, hal 52-58.

Basudewa, Dewa Gede Y. 2014. "Arca Berwahana Nandi di Pura Puseh Batubulan, Kecamatan Sukawati, Gianyar". Forum Arkeologi. Volume 27, Nomor 3, November 2014 (219 - 228).

Darta, I Ketut, dkk. 1983. Laporan Peninjauan Kekunaan di Pura Penataran Kacang Bubuan, Desa Mas, Gianyar. Gianyar: Suaka Peninggalan Sejarah dan Purbakala Propinsi Bali-NTBNTT.

Juliawati, Putu Eka. 2015. "Proses Pembentukan Budaya Tinggalan Arkeologi Di Kabupaten Badung". Forum Arkeologi. Volume 28, Nomor 1, April 2015 (47 - 56). Balai Arkeologi Denpasar.

Kompiang Gede, Dewa. 1993. "Arca Bercorak Megalitik Merajan Pasek Mengwi Badung".

Forum Arkeologi. Balai Arkeologi Denpasar. Volume 6, No 1, Maret 1993. Hal. 38-43.

Kusumawati, Ayu. 2011."Kemajemukan Tradisi Megalitik di Indonesia". Forum Arkeologi. TH. XXIV No. 3
November 2011. Balai Arkeologi Denpasar.

Lelono, T.M. Hari. 2016. "Relief Candi Sebagai Media Efektif Untuk Menyampaikan Moral-Didaktif Pada Masa Jawa Kuna". Berkala Arkeologi. Vol. 36. No 1 Mei 2016 (99-116). Balai Arkeologi Yogyakarta.

Maulana, Ratnaesih. 1984. Ikonografi Hindu. Fakultas Sastra

Universitas Indonesia.

Rema, Nyoman. 2014. "Tradisi Pemujaan Leluhur Pada Masyarakat Hindu di Bali”. Forum Arkeologi. Volume 27, Nomor 1, April 2014 (1-12). Denpasar.

Soekmono, R. 1973. Sejarah Kebudayaan Indonesia I dan II. Jakarta: Yayasan Kanisius.

Suantika, I Wayan. 2013. “Arca Garuda di Pura Gelang Agung, Buangga, Getasan, Petang, Badung". Forum Arkeologi Vol 26, No. 1 April, Denpasar: Balai Arkeologi Denpasar.

Suastika, I Made. 1997. "Arca Megalitik di Desa Tejakula", Forum Arkeologi, No 1. Juni. Halaman:18-28. Denpasar. Balai Arkeologi Denpasar.

Sukendar, Haris. 1984. "Tinjauan Arca Megalitik Tinggihari dan sekitarnya",. Berkala Arkeologi, Vol V, No 2, september hal. 1-16. Balai Arkeologi Yogyakarta.

Sulistyanto, Bambang. 1985. "Pengaruh Tantrayana di Kawasan Nusantara". Berkala Arkeologi. 
Vol VI (2): 48-60. Balai

Arkeolog Yogyakarta.

Sunarya, I Nyoman. 2008. "Desa Peguyangan, Dalam Perspektif Arkeologi". Forum Arkeologi. Volume 21, No 1, Mei 2008. Denpasar. Balai Arkeologi Denpasar. Hal. 153-157.

Suriyanto, Rusyad Adi. 2016. “Arkeologi Forensik: Perkembangan dan Capaiannya di Indonesia". Berkala Arkeologi. Vol. 36. No 1 Mei 2016 (45-70). Balai Arkeologi Yogyakarta.

Titasari, Coleta Palupi. 2008. "Mitologi di Balik Pahatan Relief Naga Pada Bangunan Suci". Pusaka Budaya dan Nilai-Nilai Religiusitas. Denpasar: Jurusan Arkeologi Universitas Udayana. 